\title{
Capital Market and Economic Growth in Nigeria: An Autoregressive Distributed Lag (ARDL) Bounds Testing Approach
}

\author{
${ }^{1}$ Panan Danladi Gwaison, ${ }^{2}$ Livinus Nkuri Maimako \& ${ }^{3}$ Pokyes Shekara Mwolchet \\ ${ }^{1}$ Economics and Management science Department Nigeria Police Academy Wudil-Kano,Nigeria \\ ${ }^{2}$ Accounting Department University of Jos, Nigeria \\ ${ }^{3}$ Department of Economics College of Education, Gindiri, Plateau State, Nigeria.
}

Email: panan_gwaison@yahoo.com

\begin{abstract}
The role of capital market in growth and development of any economy need not to be over emphasized. The capital market is a complex institution and mechanisms through which economic units desirous to invest their surplus fund, interact directly or through financial intermediaries with those who wish to procure funds for their businesses. The Nigerian capital market which started operations in mid-1961 with eight stocks and equities; with about seven United Kingdom (UK) firms quoted on the Nigerian Stock Exchange (NSE) which had, at the same time, dual quotations on the London Stock Exchange. This study examined the impact of capital market on economic growth in Nigeria from 1981 to 2018. The expo facto research design was adopted for this study. The time series data for the study were sourced from CBN statistical bulletin. Autoregressive Distributed Lag (ARDL) was used with the aid of e-view 10 software. The ARDL Bounds test revealed the existence of long run relationship among the variables. The result revealed that market capitalization has positive and insignificant effects on economic growth both in the short and long run. There is unidirectional causality among the variables. The study recommended that, regulatory authorities should restore confidence to the market by ensuring transparency and fair trading dealings and transactions in the market to enhance economic growth. There should be improvement in the moribund market capitalization, by encouraging more foreign investors to participate in the market, maintain state of the art technology like automated trading and settlement practices, electronic fund clearance and eliminate physical transfer of shares.
\end{abstract}

Keywords: Capital market, ARDL, economic growth, bounds test, causality

\section{Introduction}

The role of capital market in growth and development of any economy need not to be over emphasized. The capital market is a complex institution and mechanisms through which economic units desirous to invest their surplus fund, interact directly or through financial intermediaries with those who wish to procure funds for their businesses. Okereke (2000) describes the capital market as constituting of market and institutions that facilitates the issuance and secondary trading of long-term financial instruments. Unlike the money market that represents the short-end of financial system that provides facilities for claims and obligations with maturity vary from one day to a year, the capital market provides government at all levels an effective way of financing public projects; thus playing a vital role in stimulating industrial as well as economic growth and development.

The theoretical framework on the effects of capital market on economic growth dates back to the work of Schumpeter, (1911) which explained that a well- developed financial system can facilitate technological innovation and economic growth through the provision of financial services and resources to investors. The above argument of Schumpeter, (1911) was later 
advanced as the McKinnon, (1973) hypothesis, which is a policy analysis tool for developing countries with strong recommendation and high priority on the efficiency of financial systems in facilitating capital accumulation and financial intermediation. The above hypothesis became formalized and popularized through the endogenous growth models of Fry (1988), Greenwood and Jovanovic (1990) and Pagano (1993) which specify explicitly the modeling of the link between financial intermediation role of capital markets and growth indicators. These models have identified the capital market as an institution that contributes to the economic growth of emerging economies, they are also considered as a variable in explaining the economic growth in the most-developed ones.

The Nigerian capital market which started operations in mid-1961 with eight stocks and equities; with about seven United Kingdom (UK) firms quoted on the Nigerian Stock Exchange (NSE) which had, at the same time, dual quotations on the London Stock Exchange. At the commencement of operations, the market started with 0.3 million shares worth N1.5 m in 334 deals and the value continued to grow steadily to N16.6m in 634 deals by 1970 (CBN 2004). According to Nigerian Stock Exchange report (NSE, 2009), in 1995 the Federal Government liberalized the capital market with the abrogation of Laws that prevent foreign investors from participating in the domestic capital market. This includes: The Foreign Exchange; Monitoring and Miscellaneous Provision Decree No: 17, 1995; Nigerian Investment Promotion Commission Decree No: 16, 1995; Companies and Allied Matters Decree of 1990 and Securities and Investment Act (ISA) 45 of 1999. These legislations have accorded Nigerians and foreign investors the same right, privileges and opportunities for investment in securities in the Nigerian capital markets. Other key measures included The Central Security Clearing System (CSCS) which commenced operations in April 1997. It is a central depository for all the share certificates of quoted securities including new issues.

The Nigeria capital market is regulated by the Securities and Exchange Commission and central bank of Nigeria (CBN). The size of capital market of the country should be relative to the size of the economy if real economic progress is to be achieved by the operations of the market, since this market moves resources from people who have it to organizations that need it for productive purposes which critically smooth the growth of the economy. Other financial institutions involved in the capital market include central bank, commercial banks, insurance companies, pension funds, unit trust, issuing houses, merchant banks, etc. The traditional roles of the market are to mobilize funds from the surplus spending units to the deficit spending units for long term investments. It is also the responsibility of the capital market to create liquidity, ensure diversification of risk among others. Recently, the achievement of these goals has constituted a problem for the performance of the capital market in Nigeria. This may probably be attributed to a little amount of the total earnings of the public that actually make savings are quite small. The public companies in Nigeria are not many and in most cases, large numbers of shares issued by them are held by non-Nigerians. Also, Gbosi and Omoke (2002); and Ajie et al (2008) identified the problems faced by capital market in Nigeria to include aversion to dilution of ownership, high level of ignorance, inefficient infrastructure facilities, lack of professionals in capital market activities, paucity of monetary tools, outdated regulatory frameworks, lack of timely and easy access to information, poor investment climate, predominance of low income investors in the capital market, absence of a comprehensive mass media that deals with financial information and a relatively unsteady macroeconomic environment have adversely affected the enlargement of Nigeria's capital market.

However, to proffer solution to the above mentioned problems in the capital market, 
successive governments in Nigeria have adopted different policy measures to enhance capital market performance. Supporting the above view, Abdul (2014) submitted that the capital market in Nigeria has undergone series of reforms or transformation in an effort to achieve adequate economic growth at the rate needed to have feasible impact in reducing unemployment and poverty. The reasons for the reforms included to provide greater opportunities for funds to be mobilized, improved efficiency in the allotment of funds and make available information that are relevant for appraisal of the capital market. Consequently, the capital marketplace will make available variety of monetary instruments skilled enough to facilitating economic agents to pool, price and swap risk which will stimulate economic growth.

In spite of the reforms, the influence of capital market on the growth of the Nigerian economy is still unimpressive and disappointing when viewed from the nature of all the activities happening in the market. Furthermore, a number of studies have been carried out on the association between capital market and economic growth. But the outcomes are conflicting as shown in the empirical review. Therefore, difference in opinions and empirical findings on how capital market has impacted on economic growth is of serious concern, especially in Nigeria and that is what necessitated this research. Therefore, the broad objective of this study was to examine the impact of capital market on economic growth in Nigeria. Specifically, this study examined how variables of capital market such as market capitalization, number of deals, volume of transactions and interest rate have impacted on economic growth and the causal link between capital market and economic growth in Nigeria from 1981 to 2018. The paper has five-sections, namely introduction, literature review, methodology, results and discussion; and conclusion and recommendations.

\section{Literature Review}

\subsection{Theoretical review}

Attempts to investigate the association between capital market and economic growth have resulted in a number of theories and general statements which some are reviewed hereunder.

\section{Efficient Market Hypothesis (EMH)}

EMH was developed by Fama (1965) in an attempt to provide a framework for examining the efficiency of the capital market. Now, it remains one of the theoretical exploits of capital market economic growth association. The EMH was founded on the supposition that prices of securities in financial or monetary markets completely mirror all available information, because in a well-organized market, prospects or opportunities for all unexploited profit are eradicated or eliminated. An essential factor in this way of thinking is that not everybody in a financial or monetary market must be properly informed about a security or have rational or sensible expectations for its price to be driven to the position at which the well-organized markets state or condition holds. Financial markets are structured so that numerous participants can play. As long as a small number of participants keep opening their eyes for unexploited profit prospects, they will eliminate the profit opportunities that appear, because they make profits in so doing.

The EMH makes sense, because it does not require all and sundry in a market to be cognizant of what is happening to every security. In a well-organized market, all prices are always correct or accurate and reproduce market fundamentals (items that have a direct impact on future income streams of the securities). The evidence on the EMH is fairly mixed. Early 
evidence on the analysis of investment performance and mutual funds, whether stock prices reflect publicly available information, the random-walk behaviour of stock prices, and the success of so-called technical analysis was quite favourable to the EMH. However, in recent years, evidence or proof on the small-firm effect, market overreaction, excessive volatility, means reversion, and new information is not always incorporated into stock prices, suggesting that the hypothesis may not always be entirely correct. The proof seems to suggest that the efficient markets hypothesis may be a sensible point to start evaluating behaviour in monetary or financial markets but may not be generalized to all behaviour in financial market. The EMH indicates that hot tips, investment advisors' published recommendations, and technical analysis cannot help an advisor out-perform the market. The explanation for investors is to pursue to buy-and-hold strategy-purchase stocks and hold them for long periods of time. Empirical evidence generally supports these implications of the efficient markets hypothesis in the stock market.

According to Okpoto (2015) previous test of the EMH have relied on long range dependence of equity returns. It revealed that previous information has been found to be in improving predictive correctness. This report seems not to support the EMH in majority of the developing nations. Given the fact that the regulatory and institutional arrangements in the market are immature, the equity price definitely would tend to exhibit long range dependence. In a state of affairs where the market is highly and unreasonably speculative, investors will be disheartened. This has a negative effect on economic growth of any country, meaning that investors will refuse to invest in financial assets.

\section{Modern Portfolio Theory}

Portfolio theory is about finding the balance between maximizing your return and minimizing your risk. The objective is to select your investments in such as way as to diversify your risks while not reducing your expected return. While it does not replace the role of an informed investor, it can provide a powerful tool to complement an actively managed portfolio. A portfolio probably consists of a number of stocks, bonds and mutual funds. The mix of these assets constitutes portfolio allocation. How a portfolio is allocated determines its performance. During the first quarter of every year, investors typically spend a few hours reallocating their retirement accounts. Most allocation decisions are based on past performance, feelings, or some arbitrary selection process.

\section{Endogenous Growth Theory}

A number of theories and empirical papers such as have recommended that stock market development affect economic growth in developing countries. It has been a challenge in discussing the channels through which stock markets stimulates economic growth. In traditional growth theory, the growth rate is a positive function of exogenous technical progress. However, financial development is not related to economic growth, but to physical capital per worker (Pagano 1996). On the other hand, endogenous growth models show that economic growth performance is related to financial development, technology and income distribution. Greenwood and Jovanovic (1990) argued that income per capita helps determine membership in an information processing intermediacy that in turn improves investment decisions and economic growth. They incorporated the role of financial factors in models of endogenous growth to formalize the interactions between financial markets and economic growth. Due to the advances in the endogenous growth literature, recent models have been trying to identify the mechanism through which financial markets influence economic growth. 
Various channels have been suggested, firstly, financial markets can affect economic growth through efficient resource allocation. King and Levine(1996) proposed a model in which innovation activities serve as the engine of growth. A higher rate of successful innovations results in a higher growth rate of productivity. In the absence of financial markets, one might invest in projects that can be promptly liquidated, instead of investing in assets that are more productive but financially illiquid. Markets can provide individuals with less risky and liquid productive investments. Secondly, financial markets can influence economic growth through the information channel

\section{Financial Liberalization Theory}

The Financial Liberalization hypothesis as developed by McKinnon (1973) sees the role of government intervention in the financial markets as a major constraint to savings mobilization, investment, and growth. Government's role in controlling interest rates and directing credit to priority sectors of the economy in developing countries. inhibits savings mobilization and impedes the holding of financial assets, capital formation, and economic growth. Indirectly, ceiling on deposit interest rates discourages financial savings, which leads to excess liquidity outside the banking system. According to McKinnon (1973), pervasive government intervention and involvement in the financial system through the regulatory and supervisory network, particularly in controlling interest rates and the allocation of credit, tends to distort financial markets. Government intervention, thus adversely affect savings and investment decision of market participants and lead to fragmentation of financial mediation. The ultimate result is a financial repressed economy. The central idea of McKinnon (1973) is that financial markets should be liberalized and allocation of credit determinant by the free market. In this case, the real interest rate will adjust to its equilibrium levels and low yielding projects will be eliminated. This will lead to increase in overall efficiency of investment, savings and total real supply of credit would increase. This in turn induces a higher volume of investment which will then lead to economic growth.

The main critique of the financial liberalization theory emanates from the imperfect information Paradigm. This school of thought disagrees with the proposition of these scholars and examines the problem of financial development in the context of information asymmetry and costly information that results in credit rationing. As observed by Joseph Stiglitz (1981), asymmetric information leads to two serious problems, first, adverse selection and second, moral hazard. The implication is that the information asymmetries of higher interest rates which actually follow financial reforms and financial liberalization policies in particular exacerbate risk taking throughout the economy and hence threatens the stability of the financial system, which can easily lead to financial crises while the Feedback theory suggests a two-way causality between economic growth and financial development. The analysis is as follows: A country with well - developed financial markets could stimulate and promote high economic growth through technology changes, and product and services innovation (Schumpeter,1911)]; this in turn will create high demand in financial arrangements and services. As the financial institutions effectively respond to this demand, higher economic performance is ensured. In this regard, both financial development and economic growth are positively interdependent and their relationship could lead to feed- back causality (Khan, 1991).

\subsection{Empirical Review}

A number of literatures exist on capital market and economic growth. Some of this studies 
were review below.

Afolabi (2015) empirically examined the impact of the Nigerian Capital Market on the Nigerian economy looking at a 20 years period from 1992 to 2011. The Nigerian Capital Market was proxy as Market Capitalization against some variables of the economy such as Gross Domestic Product (GDP), Foreign Direct Investment, Inflation Rates, Total New Issues, Value of Transaction and Total Listing. Using the multiple regression analysis, the study finds that Capital Market has an insignificant impact on the Economy within the period under review. The study therefore advised that policies and measures that would boost investors' confidence should be enshrined in the running of Nigerian Capital Market so that it could contribute significantly to the growth of Nigerian economy noting that all elements of the market are essential ingredients to the development of a nation.

Atoyebi, Ishola, Kadiri, Adekunjo and Ogundeji, (2013) seek to determine the impact of capital market on economic growth in Nigeria using annual data from 1981 to 2010 . In their empirical analysis, ordinary least square test was used to verify the statistical significance of the variables used and vector auto regression technique to determine the long run relationship within the variables in their study. Their empirical investigations revealed that two variables are statistically significant at $10 \%$ and these variables are market index and market capitalization. Also the coefficient value of these two variables suggest that a percentage increase in market index and market capitalization will bring about on the average 33.7 and 44.8 percentage increase in reel GDP. Their findings based on Johanson cointegration technique and vector auto regression suggested three co-integrating equation at $5 \%$ level of significant while the vector auto regression suggested the existence of long run relationship between stock market and reel GDP. The stability in the system was also determined through the vector autoregressive technique. Their study recommended that there is need to address the reported case of abuse and sharp practices by some companies in the market. There is also the need to boost the value of transactions in the Nigerian capital market; there is need for availability of more investment instruments such as derivatives, convertibles, future, and swaps options in the market.

Okoye, Modebe, Taiwo and Okorie (2016) investigated the relationship between capital market development and economic growth using data on GDP (proxy for economic growth), market capitalization ratio; value traded ratio and stock market turnover ratio (proxies for capital market development) over the period1981-2014. Employing the econometric methodology of the vector error correction model, their study showed that in the short-run, market capitalization ratio and turnover ratio have significant negative effect on aggregate national output (GDP). Their study also showed positive effect of value traded ratio as well as negative effect of inflation rate on GDP though not significant. Their long-run estimate showed that all the exogenous variables have significant negative impact on GDP and that changes in market capitalization ratio, value traded ratio and turnover ratio produce more than proportionate changes in GDP. With an adjustment speed of about 91.12 percent, their model presents an inherent capacity to overcome short-run disequilibrium. Their Granger causality test result shows evidence of causal impact of market capitalization ratio, value traded ratio and turnover ratio on aggregate national output. Their study further shows uni-directional causality from GDP to inflation. Their study established that stock market development constitutes a significant determinant of economic growth in Nigeria.

Yadirichukwu, and Chigbu, (2014) examined the impact of capital market on economic 
growth in Nigeria. In their study, a time-series research design relying extensively on secondary data covering 1985 -2012was adopted. Their study utilized regression analysis as data analysis method incorporating multivariate co-integration and error correction to examine characteristics of time series data adopting disaggregate the capital market indices approach. Their finding suggested that two exhibited positive while two exhibited inverse and statistically significant relationship with economic growth. Their study recommended that relevant regulatory agencies should focus on enhancing efficiency and transparency of market to improve investor's confidence. Therefore the need for effective and favourable macroeconomic environment to facilitate economic growth and ensure that channels of capital market induced growth are built around effective systems; and that policy institutions are active in making systemic checks and appropriate policy innovations to ensure capital market led economic growth.

Taiwo, Adedayo and Evawere (2016) evaluated the contribution of capital market to the growth of Nigeria's economy. Their study estimated error correction model for economic growth in Nigeria, using Vector Error Correction techniques on an annual time series data spanning from 1981 to 2014. The data used in their study were subjected to Phillip Perron Unit Root Test at level and first difference. Their result showed that, atone percent significance level, all the variables were stationary at first differencing. Their result of the normalized co integrated series revealed that market capitalization rate, total value of listed securities, labor force participation rate, accumulated savings and capital formation are significant macroeconomic determinant factors of economic growth in Nigeria. The study recommended that, for the capital market to realizes its full potentials, its environment must be enabled to promote and encourage investment opportunities for both local and international investors, since the stock market operates in a macroeconomic environment. Consequently, an improvement in the Nigerian trading system with the aim of increasing the ease with which investors can purchase and sell shares, could guarantee the stock market liquidity.

Odo, Anoke, Onyeisi and Chukwu (2017) investigated the impact of capital market on economic growth in Nigeria from 1986 to 2016. They employed Auto Regressive Distributed Lag bound testing and VAR Granger causality econometric tools of estimation to test the variables in the model. The result of the estimation revealed a stable long run association between the explained and explanatory variables as supported by the greater bound value of 10.58. The finding of the ARDL revealed that market capitalization has positive significant association with economic growth; also, stock traded total value indicated a negative insignificant link with economic growth, all in the short run. The findings further showed that market capitalization and stock traded total value percent of GDP exhibited a negative insignificant link with economic growth in the long run within the period of the study. Findings of VAR Granger test revealed that, causality was seen from MCAPGDP to GGDP.

Muritala and Ogunji (2017) critically studied the association between the capital market and economic growth in Nigeria (1980-2015). Unit root, Co-integration and ECM methods of econometrics were employed. The finding showed that total new issue, market capitalization, and total listing positively impact on the economy. Meanwhile, the value of the transaction has impacted on real gross domestic product negatively. 


\section{Research Method}

\subsection{Data}

The expo facto research design was adopted for this study. Ex post facto research design is a non- experimental research technique in which preexisting groups are compared on some dependent variable. Ex-post facto research involves past events where data already exist. This research technique will be used due to its suitability in research survey of this nature.

Secondary data was collected on each of the above stated variables, covering the period of 1981 to 2018 . The choice of this period is to make room for a broad coverage of the capital market indicators, as well as the investigation of both the short run and long run relationship between capital market development and economic growth in Nigeria. These annual data series were collected majorly from CBN Statistical Bulletin of 2014, CBN Annual Report and Statement of Accounts (various issues), NSE books, and SEC Market Bulletins.

The estimation procedure for this study is the multivariant regression approach starting from unit root test for stationarity, ARDL for the determination of the long run relationship among correlated variables of order $\mathrm{I}(0)$ and $\mathrm{I}(1)$ and the short and long run dynamic nature.

\subsection{Model specifications}

The notion of growth as increased stocks of capital goods (means of production) involved a series of equations which showed the relationship between labour-time, capital goods, output, and investment. Therefore, economic growth (measured by real gross domestic product)is estimated as a function of savings by deposit mobilization, capital accumulation, labour supply, total listed stock market securities and the contribution of the stock market. These were measured respectively by deposit money banks, gross fixed capital formation, active labor force participation, total listed assets and stock market capitalization.

$$
\begin{aligned}
& \mathrm{RGDP}=\mathrm{f}(\mathrm{MCAP}, \mathrm{SAV}, \mathrm{GFCF}, \mathrm{LABF}, \mathrm{TLA}) \ldots \ldots \ldots \ldots \\
& R G D P=\alpha_{0}+\alpha_{1} M C A P+\alpha_{2} S A V+\alpha_{3} G F C F+\alpha_{4} L A B F+\alpha_{5} T L A+\mu_{i}
\end{aligned}
$$

Where:

RGDP $=$ Real Gross Domestic Product at constant factor cost

MCAP $=$ Stock Market Capitalization

$\mathrm{SAV}=$ Savings Accumulation

GFCF $=$ Gross Fixed Capital Formation

$\mathrm{LABF}=$ Labour Force

TLA $=$ Total Listed Securities

$$
\mu t=\text { Error Term }
$$

$\dot{\alpha} 0=$ The constant parameter;

$\dot{\alpha} 1, \dot{\alpha} 2, \dot{\alpha} 3 \dot{\alpha} 4$, and $\dot{\alpha} 5=$ The slope parameters

Apriori expectation: On the apriori: $\dot{\alpha} 1, \dot{\alpha} 2, \dot{\alpha} 3 \dot{\alpha} 4, \dot{\alpha} 4>0$.

The techniques that were employed to analyze our data are: unit root test via Augmented 
Dickey Fuller test (ADF) and Autoregressive Distributed Lag (ARDL). The ADF unit root test helps to ascertain stationarity of the variables, and the general form of the ADF is presented thus:

$$
\Delta \mathrm{yt}=\alpha 0+\alpha 1 \mathrm{yt}-1+\Sigma \alpha 1 \Delta \mathrm{y} \mathrm{i}+\delta \mathrm{t}+\mathrm{Ut} \text { (3) }
$$

Where: $\mathrm{y}$ is a time series, $\mathrm{t}$ is a linear time trend, $\Delta$ is the first difference operator, $\alpha 0$ is a constant, $\mathrm{n}$ is the optimum number of lags in the independent variables and $\mathrm{U}$ is random error term. In order to examine the short-and long-term relations between the economic growth and capital market variables in the model, Autoregressive Distributed Lag (ARDL) was used. The reason is that estimates provided by ARDL method avoid problems such as autocorrelation and endogeneity, they are unbiased and efficient. Moreover, Autoregressive Distributed Lag (ARDL) is a long-established method of estimating cointegrating relationships, such as EngleGranger (1987) or Johansen's (1991, 1995) method, or single equation methods such as Fully Modified OLS, or Dynamic OLS either require all variables to be I(1), or require prior knowledge and specification of which variables are I(0) and which are I(1). To alleviate this problem, Pesaran and Shin (1999) and Smith (2001) showed that co-integrating systems can be estimated as ARDL models, with the advantage that the variables in the cointegrating relationship can be either $\mathrm{I}(0)$ or $\mathrm{I}(1)$, without needing to pre-specify which are $\mathrm{I}(0)$ or $\mathrm{I}(1)$. Pesaran and Shin also noted that unlike other methods of estimating cointegrating relationships, the ARDL representation does not require symmetry of lag lengths; each variable can have a different number of lag terms. Therefore, the ARDL model for this study is presented thus:

$\triangle \mathrm{R} G D P t,=C 0+C 1 \mathrm{R} G D P t-1,+C 2 M C A P t-1,+C 3 \mathrm{SAV} t-1,+C 4 \mathrm{GFCF} t-1,+$ $C 5 \mathrm{LABF} t-1, j+C 6$ TLA $t-1, j$

$$
\begin{aligned}
& \sum_{i=1}^{n 1} \alpha 1 i j \Delta R G D P_{t-1 j}+\sum_{i=0}^{n 2} \alpha_{2} i j \Delta M C A P_{t-1 j}+\sum_{i=0}^{n 3} \alpha_{2} i j \Delta S A V_{t-1 j} \\
& +\sum_{i=0}^{n 4} \alpha_{3} i j \Delta G F C F_{t-1 j}+\sum_{i=0}^{n 5} \alpha_{4} i j \Delta L A B F_{t-1 j} \\
& +\sum_{i=0}^{n 6} \alpha_{5} i j \Delta T L A_{t-1 j}+\mu t \\
& -----(4)
\end{aligned}
$$

\section{Findings and Discussions}

The empirical analysis focused mainly on descriptive statistics, estimation of the regression model and post estimate tests.

\subsection{Descriptive Statistics}

The essence of the descriptive statistics is to ascertain stability of the time series. 
Table 1. Descriptive Statistics

\begin{tabular}{llllll}
\hline Descriptive Statistics & RGDP & MCAP & SAV & GFCF & TLA \\
\hline Mean & 348497.7 & 3767.466 & 2077.531 & 60.92857 & 2116452. \\
Median & 281407.4 & 285.8000 & 200.0700 & 40.90000 & 322764.9 \\
Maximum & 986202.0 & 19077.40 & 12813.42 & 142.3000 & 9122200. \\
Minimum & 94.33000 & 5.000000 & 6.560000 & 6.300000 & 8582.900 \\
Std. Dev. & 248953.2 & 5926.319 & 3481.212 & 39.98805 & 3224455. \\
Skewness & 0.691993 & 1.377490 & 1.721678 & 0.698553 & 1.291975 \\
Kurtosis & 2.957677 & 3.417763 & 4.822128 & 2.076829 & 2.912855 \\
Jarque-Bera & 2.795926 & 11.32313 & 22.13290 & 4.089382 & 9.748066 \\
Probability & 0.007100 & 0.003477 & 0.000016 & 0.009420 & 0.007642 \\
Sum & 12197420 & 131861.3 & 72713.58 & 2132.500 & 74075810 \\
Sum Sq. Dev. & $2.11 \mathrm{E}+12$ & $1.19 \mathrm{E}+09$ & $4.12 \mathrm{E}+08$ & 54367.49 & $3.54 \mathrm{E}+14$ \\
Observations & 35 & 35 & 35 & 35 & 35 \\
\hline
\end{tabular}

Source: Authors Computation, 2019 (Eview-10)

The descriptive statistics reported in Table 1, indicates that the variables are leptokurtic in nature since their values for kurtosis are more than three. This indicates a flatter than normal distribution. Specifically, the Kurtosis test reveals that the variables have large tails. The Skewness test result showed positive values for all the series, meaning that they have high tails. The probability of Jarque-Bera statistics suggests that the variables have normal distribution.

\subsection{Unit Root Test Result}

The test for the stationarity status of all variables in the model to establish their order of integration proceeds the ARDL bounds test, the reason for this is to be sure that the variables are stationary at level 1(0) and first difference 1(1) only but not second difference I(2) so as to avoid spurious regression results. Inferences in the bounds testing procedure through the computed F-statistics for bounds testing are based on the assumption that the variables are level 1(0) or first-difference 1(1) stationary. Therefore, the ADF method was used to test for the stationarity of the variables in the model. See Table 4.2 below.

Table 2. Summary of Unit Root Test Results

\begin{tabular}{|c|c|c|c|}
\hline Variables & $\begin{array}{lll}\text { ADF Test } & \text { Statistic(at first } \\
\text { difference) }\end{array}$ & $\begin{array}{l}\text { Order of } \\
\text { Integration }\end{array}$ & p-value \\
\hline RGDP & $-4.785579(-2.951125)^{* *}$ & $I(1)$ & 0.0005 \\
\hline$M C A P$ & $-5.726940(-2.951125)^{* *}$ & $I(0)$ & 0.0000 \\
\hline$S A V$ & $5.571282(-2.986225) * *$ & $I(1)$ & 0.0000 \\
\hline$G F C F$ & $-4.680745(-2.951125) * *$ & $I(1)$ & 0.0006 \\
\hline$T L A$ & $-5.569444(-2.981038)$ & $I(0)$ & 0.0001 \\
\hline
\end{tabular}

Source: Authors Computation, 2019 (Eview-10)

From table 2 Since the variables were integrated of order 1(0) and 1(1) that mixed order of integration. It is suitable for the application of ARDL approach. 
Table 3. ARDL Bounds Test for Co-integration

\begin{tabular}{lllll}
\hline \hline Test Statistic & Value & Signif. & $\mathrm{I}(0)$ & $\mathrm{I}(1)$ \\
\hline \hline & & & \multicolumn{2}{l}{ Asymptotic: $\mathrm{n}=35$} \\
F-statistic & \multirow{3}{*}{8.845192} & $10 \%$ & 2.2 & 3.09 \\
K & 4 & $5 \%$ & 2.56 & 3.49 \\
& & $2.5 \%$ & 2.88 & 3.87 \\
& & $1 \%$ & 3.29 & 4.37 \\
\hline
\end{tabular}

Source: Authors Computation, 2019 (Eview-10)

From the ARDL bounds test result, it is clear that there is a long run relationship amongst the variables (RGDP, MCAP, SAV, GFCF,LABF and TLA). This is because the computed Fstatistic of about 8.8 is higher than the upper critical bounds at $1 \%, 2.5 \%, 5 \%$ and $10 \%$ critical values. This provided evidence to reject the null hypothesis of no cointegration at $5 \%$ and $10 \%$ significance level for the growth model. It can therefore be concluded from the ARDL bounds test that there is a long-run relationship among the variables. Therefore, this study illustrate that capital market variables have a long run relationship with the Nigerian economic growth.

Table 4. Estimated ARDL Long Run Coefficients

\begin{tabular}{lllll}
\hline \hline Variable & \multicolumn{2}{l}{ Coefficient Std. Error } & t-Statistic & Prob. \\
\hline \hline MCAP & 3.447010 & 9.251361 & 0.372595 & 0.7130 \\
SAV & 77.65499 & 14.26769 & 5.442718 & 0.0000 \\
GFCF & -2780.599 & 784.9647 & -3.542324 & 0.0018 \\
TLA & 0.004530 & 0.007829 & 0.578527 & 0.5688 \\
C & 356253.0 & 29270.29 & 12.17115 & 0.0000 \\
\hline \hline
\end{tabular}

Source: Authors Computation, 2019 (Eview-10)

The estimated ARDL long run coefficients in Table 4 revealed that market capitalization and total listed securities have positive but insignificant relationship with economic growth. This does not conform to the a priori expectations. Gross Fixed Capital Formation has a negative but significant relationship with economic growth. The result also revealed that Savings accumulation has a positive and significant relationship with economic growth. In addition, it can be deduced that market capitalization, number of deals and total listed securities will enhance economic growth in the long-run. 
Table 5. Error Correction model test

\begin{tabular}{lllll}
\hline \hline Variable & Coefficient & Std. Error & t-Statistic & Prob. \\
\hline \hline D(MCAP) & 5.440808 & 3.292391 & 1.652540 & 0.1109 \\
D(SAV) & 37.29050 & 11.76733 & 3.168984 & 0.0040 \\
D(GFCF) & -45.36066 & 483.2147 & -0.093873 & 0.9260 \\
D(TLA) & -0.002609 & 0.010105 & -0.258166 & 0.7984 \\
ECM(-1) & -0.668179 & 0.285995 & -2.336335 & 0.0278 \\
& & & & 27801.52 \\
R-squared & 0.504957 & Mean dependent var & 36579.42 \\
Adjusted R-squared & 0.5038250 & S.D. dependent var & 24.04091 \\
S.E. of regression & 37272.43 & Akaike info criterion & 24.27444 \\
Sum squared resid & $3.47 E+10$ & Schwarz criterion & 24.11562 \\
Log likelihood & -355.6136 & Hannan-Quinn criter. & \\
Durbin-Watson stat & 2.315275 & & & \\
\hline \hline
\end{tabular}

Source: Authors Computation, 2019 (Eview-10)

Table 5 showed the result of the short-run dynamic coefficients associated with the long-run relationships obtained from the ECM equation. The Error Correction Term in the model has the right sign (i.e., negative) and statistically significant this satisfied the conventional level. This indicates adjustment to long-term equilibrium in the dynamic model. Put differently, it indicates it adjustment from short run equilibrium to long-run equilibrium in the dynamic model. This implies that deviations from the short-term growth rate in economic growth adjust quickly to long run equilibrium at $66.8 \%$. The Durbin Watson (DW) value of 2.3 which is approximately 2.0, suggests that the model is free from autocorrelation. Moreover, as expected, market capitalization in the short- run has positive and insignificant effect at $5 \%$ level of significance on economic growth. This means that market capitalization enhanced economic growth in the short-run. The results showed that a unit increase in market capitalization will increase economic growth. Furthermore, total listed securities in the shortrun has negative and insignificant effect on economic growth. The results showed that a unit increase in total listed securities will decrease economic growth. In addition, Gross Fixed Capital Formation and Savings accumulation in the short run have negative and positive effect respectively on economic growth but both variables have significant effect on economic growth. This depicts that the variables have the potentials to adjust to stable long run relationship or equilibrium with economic growth. 
Table 6. Pairwise Granger Causality Tests

\begin{tabular}{lccc}
\hline \hline Null Hypothesis: & Obs & F-Statistic & Prob. \\
\hline \hline MCAP does not Granger Cause RGDP & 34 & 1.83098 & 0.1783 \\
RGDP does not Granger Cause MCAP & & 2.67565 & 0.0058 \\
SAV does not Granger Cause RGDP & 32 & 1.47596 & 0.2464 \\
RGDP does not Granger Cause SAV & & 2.71754 & 0.0085 \\
GFCF does not Granger Cause RGDP & 34 & 0.80079 & 0.4587 \\
RGDP does not Granger Cause GFCF & & 4.83832 & 0.0154 \\
TLA does not Granger Cause RGDP & 34 & 1.13601 & 0.3350 \\
RGDP does not Granger Cause TLA & & 2.06566 & 0.0266 \\
\hline \hline
\end{tabular}

Source: Authors Computation, 2019 (Eview-10)

The causality results in table 6 indicated a unidirectional relationship between the variables. RGDP causes changes in MCAP but MCAP does not cause changes in RGDP. RGDP causes changes in SAV but SAV does not cause changes in RGDP. RGDP causes changes in GFCF but GFCF does not cause changes in RGDP. RGDP causes changes in TLA but TLA does not cause changes in RGDP.

\section{Post Estimate Tests}

Post estimate tests were employed to examine the reliability of the estimated model for prediction or policy purposes. Specifically, Ramsey Reset Test, Breusch-Godfrey Serial Correlation LM Test, Heteroskedasticity Test: BreuschPagan-Godfrey and normality tests were applied. The post estimate tests revealed that the ARDL model passed all the diagnostic tests considered.

\section{Normal Distribution Test}

It is a test for normality distribution assumption of the error term. The result shows the properties of the residuals. Importantly, the Jarque-Bera statistics is a test which shows whether the residual from our equation violates the normality assumption of the OLS technique. 

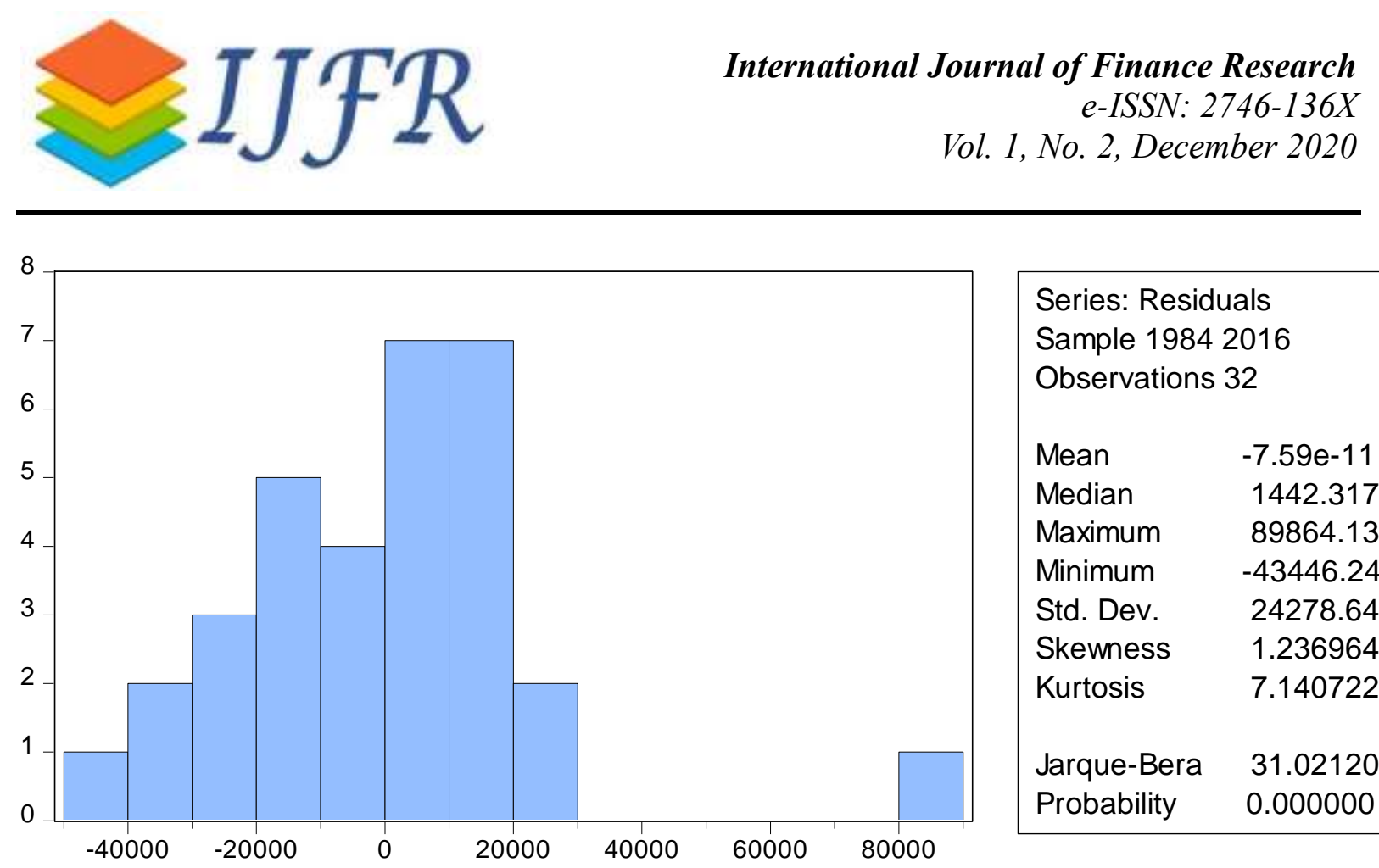

\begin{tabular}{|ll|}
\hline \multicolumn{2}{|l|}{ Series: Residuals } \\
Sample 1984 2016 \\
Observations 32 \\
Mean & $-7.59 \mathrm{e}-11$ \\
Median & 1442.317 \\
Maximum & 89864.13 \\
Minimum & -43446.24 \\
Std. Dev. & 24278.64 \\
Skewness & 1.236964 \\
Kurtosis & 7.140722 \\
& \\
Jarque-Bera & 31.02120 \\
Probability & 0.000000 \\
\hline
\end{tabular}

Figure 1. Testing the normality assumption

Source: Authors Computation, 2019 (Eview-10)

Ho: The sample data are not significantly different than a normal population

H1: The sample data are significantly different than a normal population.

Probabilities $>0.05$ accept the null hypothesis Probabilities $<0.05$ reject the null hypothesis From the result, the probability is 0.0000 and this is greater than 0.05 at $5 \%$ significant level and therefore, the null hypothesis is accepted. This means that the residuals are normally distributed.

\section{Serial correlation}

The regression model is free of serial correlation going by the result of the serial LM test.

Table 7. Breusch-Godfrey Serial Correlation LM Test

\begin{tabular}{llll}
\hline \hline F-statistic & 0.866593 & Prob. F(2,20) & 0.4356 \\
Obs*R-squared & 2.551947 & Prob. Chi-Square(2) & 0.2792 \\
\hline \hline
\end{tabular}

Source: Authors Computation, 2019 (Eview-10)

From table 7 the Prob. Chi-square gave 0.2792, and it's greater than 0.05; thus we accept the null hypothesis that there is no serial correlation among the variables used in the model.

Table 8. Heteroskedasticity Test: Breusch-Pagan-Godfrey

\begin{tabular}{llll}
\hline \hline F-statistic & 3.666015 & Prob. F(9,22) & 0.0062 \\
Obs*R-squared & 19.19863 & Prob. Chi-Square(9) & 0.0236 \\
Scaled explained SS & 27.86154 & Prob. Chi-Square(9) & 0.0010 \\
\hline \hline
\end{tabular}

Source: Authors Computation, 2019 (Eview-10)

From table 8, the Prob. F-value gave 0.5199, and it's greater than 0.05; thus we accept the null hypothesis that there is no heteroscedsticity among the variables used in the model 


\section{Parameter Instability Test- Ramsey RESET Test}

The Ramsey's Regression Specification Error (RESET) test is necessary for parameter stability. This is a general test for specification errors that may arise from omitted variables, incorrect functional forms and correlation between explanatory variables and error term.

Table 9. Ramsey RESET Test

\begin{tabular}{llll}
\hline \hline & Value & df & Probability \\
\hline t-statistic & 1.532238 & 24 & 0.1385 \\
F-statistic & 2.347754 & $(1,24)$ & 0.1385 \\
Likelihood ratio & 2.799877 & 1 & 0.0943 \\
& & & \\
F-test summary: & & & Mean Squares \\
& Sum of Sq. & df & $3.09 \mathrm{E}+09$ \\
Test SSR & $3.09 \mathrm{E}+09$ & 1 & $1.39 \mathrm{E}+09$ \\
Restricted SSR & $3.47 \mathrm{E}+10$ & 25 & $1.32 \mathrm{E}+09$ \\
Unrestricted SSR & $3.16 \mathrm{E}+10$ & 24 & \\
& & & \\
LR test summary: & & & \\
Restricted LogL & Value & \\
Unrestricted LogL & -355.6136 & & \\
\hline \hline
\end{tabular}

Source: Authors Computation, 2019 (Eview-10)

Output from the test reports the test regression and the F-ratio and log-likelihood ratio for testing the hypothesis that the probabilities of the powers of fitted values are all less than 0.05 . The results in table 9 show that there is no presence of specification error as the test statistics are significant at all level of significance.

\section{Parameter Instability Test- CUSUM test \&CUSUM SQUARE TEST}

CUSUM test and CUSUM squares test does not require specifying a particular date and it plots the cumulative sum of the recursive residuals together with the $5 \%$ critical lines. The CUSUM test and CUSUM squares test indicates parameter instability if the cumulative sum goes outside the area between the two critical lines. 


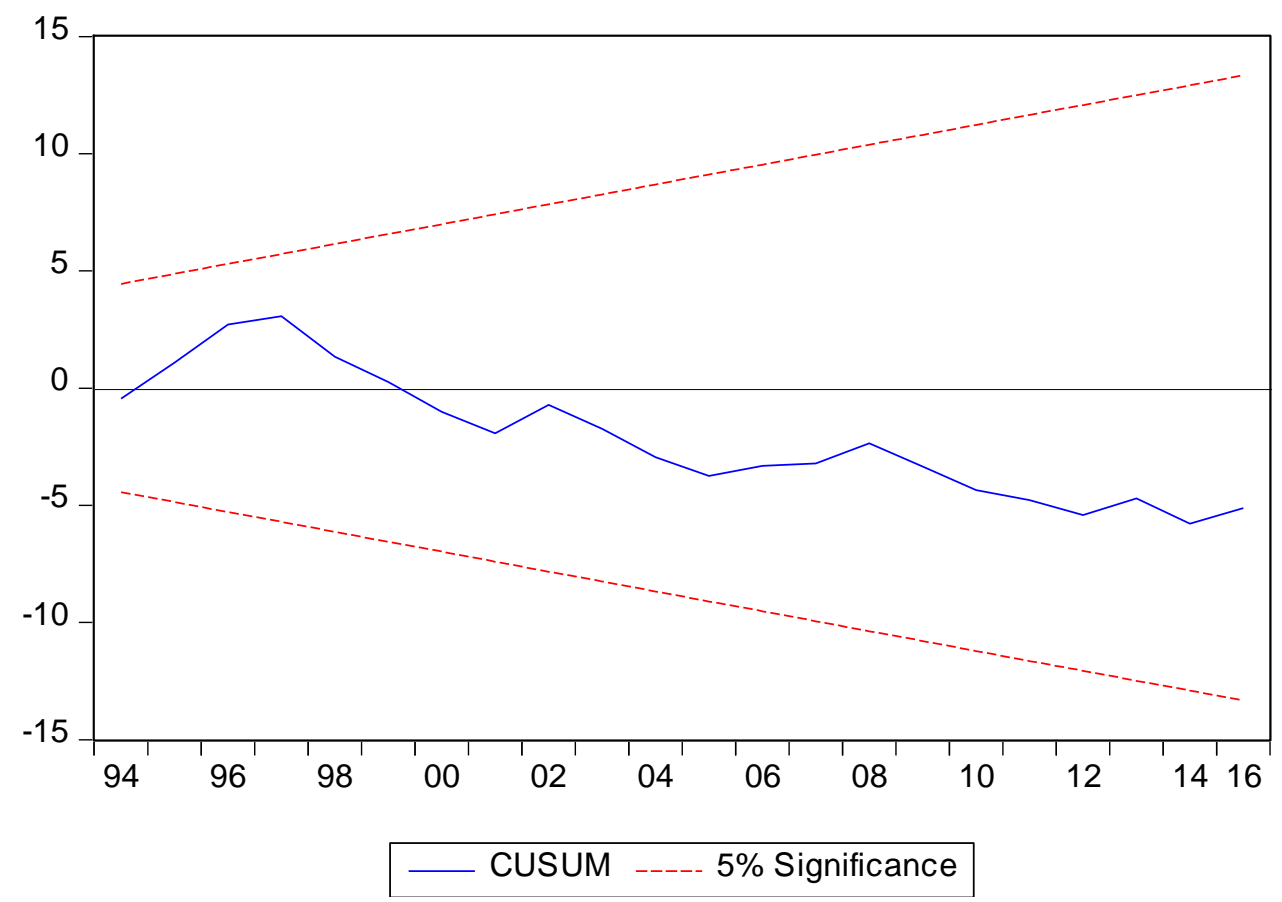

Figure 2. CUSUM test

Source: Authors Computation, 2019 (Eview-10)

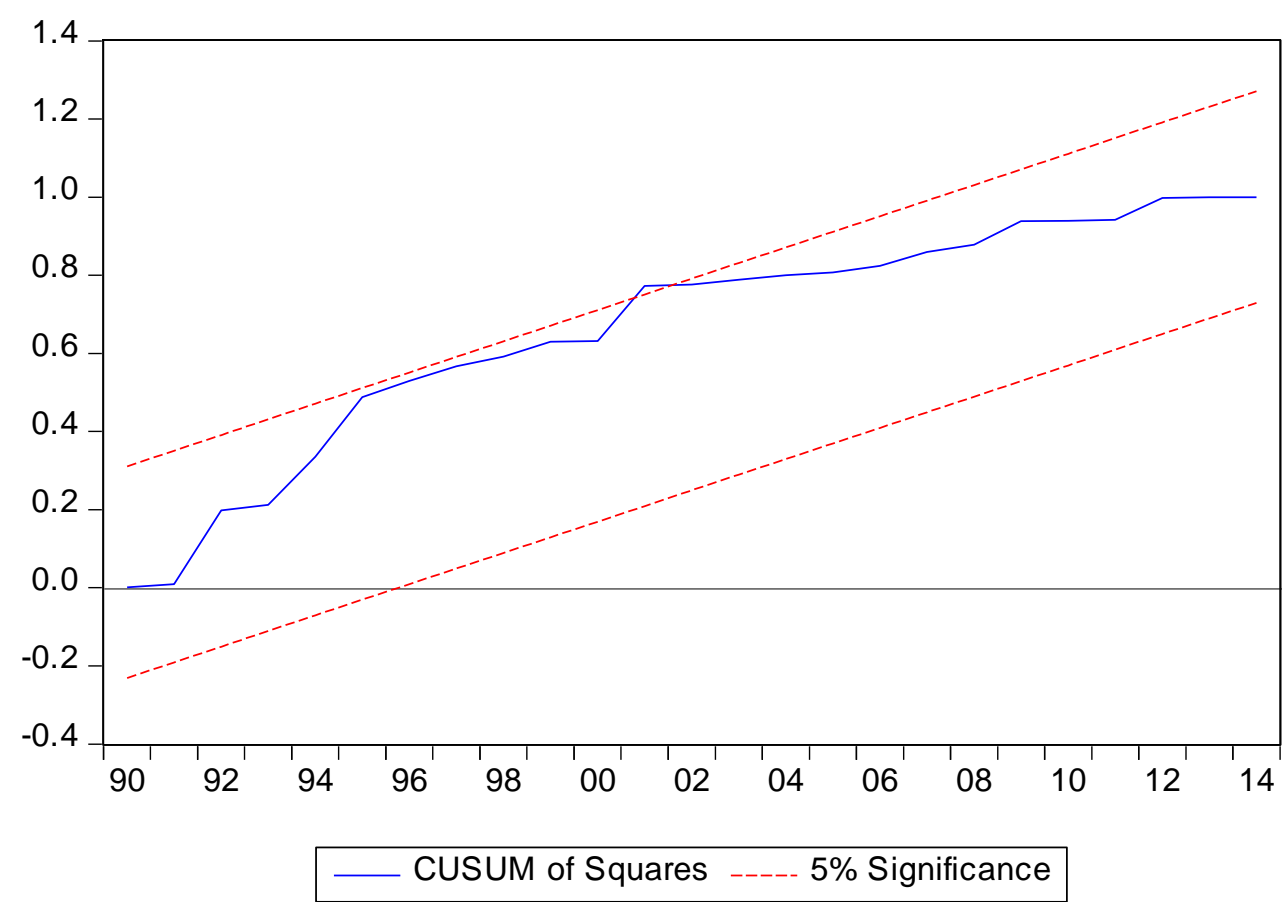

Figure 3. CUSUM SQUARE TEST

Source: Authors Computation, 2019 (Eview-10)

The CUSUM test and CUSUM squares test results in figure 2 indicated that the parameter were stable since they are within the two critical lines. 


\section{Conclusions}

The study on capital market and economic growth in Nigeria from 1981-2018 is of great important to the Nigerian economy. This is because capital market plays an important role in the growth process of the economy. With the utilization of data on gross domestic product, interest rate, value of transaction, market capitalization and number of deals from CBN Statistical Bulletin and the use of ARDL to capture the short and long-run relationship between endogenous and exogenous variables. The result revealed that market capitalization has positive and insignificant effects on economic growth both in the short and long run. Gross Fixed Capital Formation has a negative but significant relationship with economic growth. The result also revealed that Savings accumulation has a positive and significant relationship with economic growth in the long run but negative and insignificant effect on economic growth in the short run. However, the total listed securities has a negative and insignificant effect on economic growth in the short run but it has positive and significant effect on economic growth in the long run. The result also revealed a unidirectional causality between the variables. The study therefore concluded that capital market has positively and insignificantly impacted on economic growth in Nigeria between the period of study.

The study recommended that there should be improvement in the moribund market capitalization, by encouraging more foreign investors to participate in the market, maintain state of the art technology like automated trading and settlement practices, electronic fund clearance and eliminate physical transfer of shares. There is also need to restore confidence to the market by regulatory authorities through ensuring transparency and fair trading transactions and dealings in the stock exchange. The Nigeria stock exchange will have to reduce the hurdle or soften the requirements for corporation or business to be able to access such cheap funds. There should be a strong need to put in place policy measures that would guarantee competitive participation and cause investors to stop the attitude of "buy and hold" of securities which will delay rapid development of Nigerian economy. The government should also make use of the capital market in sourcing for cheap funds instead of relying entirely on the optimum benefits of the activities of the Nigeria stock exchange to accrue to the Nigerian economy. There is need for the government through the central bank to implement policy that will increase the level and size of market capitalization in the capital market. Such increase in capital market will provide the needed funds for investors for further investments and hence increased productivity in Nigeria.

\section{Acknowledgments}

We will like acknowledge our parents, spouse and children for their love and encouragement during the period of this study. Our lecturers during undergraduates and postgraduates studies Economics department university of Jos Nigeria for their selfless sacrifice in impact us with required knowledge. The Central Bank of Nigeria for providing us with the statistical data for the studies. Lastly, we will like to acknowledge the international journal of finance research for giving us this opportunity to publish free. Thank you all.

\section{References}

Atoyebi, K., Ishola, S. A., Kadiri, K. I., Adekunjo, F. O. \& Ogundeji, M. O. (2013). Capital market and economic growth in Nigeria. An empirical analysis. Journal of Humanities and Social Sciences, 6(6): 60-68.

Central Bank of Nigeria (2004), "Nigeria: Major Economic, Financial and Banking 
Indicators" Retrived from: http://www.cenbank.org/documents/Statbulletin.asp 24/9/2019

Demirgue - Kunt A, \& Asli Levin R. (1996) Stock market, corporate finance and economic growth: An overview. The World Bank Review.10(2):223-236.

Fry, M.J. (1988). Money, Interest, and Banking in Economic Development. John Hopkins University Press, Johns Hopkins Studies in Development series Baltimore and London ibacnet.org/bai2007/proceedings /Papers/2007bai7443.doc.

Khan MS, Villanueva D. (1991) Macroeconomic policies and long- term growth: a conceptual and empirical review. IMF Working Paper WP/91128, International Monetary Fund, Washington DC

Inimino, E. E., Bosco, I. E. ,\& Abuo, M. A. (2018) Capital market and economic growth in Nigeria: An autoregressive distributed lag (ARDL) bounds testing approach. International Journal of Research and Innovation in Social Science 2(4) 87-96.

King GR, Levine R.(1993) Finance and growth: Schumpeter might be right. The quarterly Journal of Economics. 108(3):717- 737

Levine R,\& Zervos S. (1996) Stock market development and long run growth. The World Bank Economic Review. 10(3):323-339

MacKinnon, R.I. (1973). Money and capital in economic development", Washington, DC: Brookings Institution. Markets, Journal of Financial Research, Vol. 26, pp. 275-299.

Muritala, T. A. and Ogunji, M. (2017). Does the capital market spur economic growth? Evidence from Nigeria. Journal of Corporate Finance Research, 11(1), 90-99

Odo, S. I., Anoke, C. I., Onyeisi, O. S. and Chukwu, B. C. (2017). Capital market indicators and economic growth in Nigeria; An autoregrssive distributed lag (ARDL) model. Asian Journal of Economics, Business and Accounting 2(3): 1-16.

Okereke, O. N. (2000). Stock market financing options for public projects in Nigeria. The Nigerian Stock Exchange Fact Book, pp. $41-49$.

Okoye, P. V. C., Okoye, J. F. N. and Ezejiofor, R. A. (2015). The impact of capital market efficiency as a panacea to the economic growth in Nigeria. International Journal of Financial Economics 4, (3), 122-134

Okpoto, S. I. (2015). Capital market and Nigeriaes economic growth (1980-2013). Journal of Policy and Development Studies 9(4), 98-112.

Pesaran, M.H. and Shin, Y. (1999). An Autoregressive Distributed Lag Modelling Approach to Cointegration Analysis. Econometrics and Economic Theory in the 20th Century: The Ragnar Frisch Centennial Symposium, Strom, S. (ed.) Cambridge University Press.

Pesaran, M.H., Shin, Y. and Smith, R. (2001). "Bounds Testing Approaches to the Analysis of Level Relationships.” Journal of Applied Econometrics, 16, 289-326.

Pagano, M. (1993), Financial Markets and Growth: An overview. European Economic Review, Vol. 37, pp. 613-622

Stiglitz J. E\& Weiss A. (1981) . Credit rationing in market with imperfect information. The 
American Economic Review. 71(3):393-410.

Schumpeter, J.A. (1911) The theory of economic development. Cambridge, MA: Harvard University Press.

Yadirichukwu, E. and Chigbu, E. E. (2014). The impact of capital market on economic growth: The Nigerian perspective. International Journal of Development and Sustainability, 3 (4), 838-864.

\section{Copyrights}

Copyright for this article is retained by the author(s), with first publication rights granted to the journal.

This is an open-access article distributed under the terms and conditions of the Creative Commons Attribution license (http://creativecommons.org/licenses/by/4.0/) 